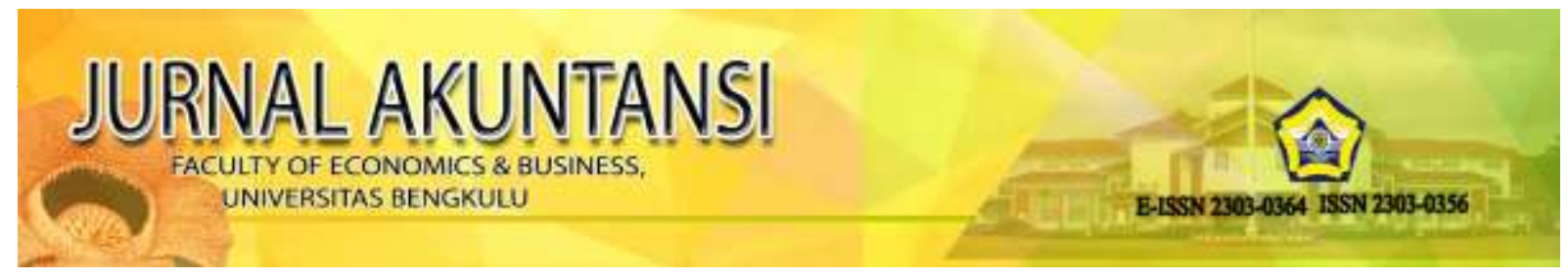

Jurnal Akuntansi

Vol. 9, No.3 2019

DOI : https://doi.org/10.33369/j.akuntansi.9.3.187-200

Hal. $187-200$

\title{
PENGARUH KEPEMILIKAN INSTITUSIONAL, DEWAN KOMISARIS INDEPENDEN, DAN KOMITE AUDIT TERHADAP NILAI PERUSAHAAN SEKTOR PERTAMBANGAN
}

\author{
The Effect of Institusional Ownership, Independent Commissioner and Audit Committees \\ on Firm Value of Mining Sector
}

\author{
Fitri Amaliyah $^{1)}$ dan Eliada Herwiyanti ${ }^{2)}$ \\ Universitas Jenderal Soedirman, Jalan Dr. H.R Boenyamin No. 708 Purwokerto, Indonesia, ${ }^{1,2)}$
}

\begin{abstract}
The purpose of the study was to determine whether there are effects of institusional ownership, independent commissioner and the audit board to the value of the company. This type of research is correlational research, with quantitative research. This study uses secondary data taken from the IDX website data. The sample used in this study proved60 companies consisting of the mining sector during the 2-year observation period. The sampling technique was carried out using the purposive sampling method. The analytical method used is multiple linear regression analysis with an analysis tool using SPSS 22. The results of this study showed that institusional ownership variables are not significant effect to the value of the company. Independent commissioner variables are not significant effect to the value of the company. While the committees variables have a significant to the value of the company. The conclusion from this research is the audit committee has a role that can increase the value of the company through the quality of the audit committee. As for institutional ownership and the number of independent boards of commissioners does not affect the value of the company.
\end{abstract}

Keywords: Iinstitusional ownership, independent commissioner, audit committees, firmvalue

\begin{abstract}
ABSTRAK
Penelitian ini bertujuan untuk mengetahui pengaruh kepemilikan institusional, dewan komisaris independen, dan komite audit terhadap nilai perusahaan. Jenis penelitian ini adalah penelitian korelasional, dengan pendekatan kuantitatif. Penelitian ini menggunakan data sekunder yang diambil dari website data BEI. Sampel yang digunakan berjumlah 60 perusahaan sektor pertambangan selama 2 tahun periode pengamatan. Teknik pengambilan sampel dilakukan dengan menggunakan metode purposive sampling. Metode analisis yang digunakan adalah analisis regresi linier berganda dengan alat analisis menggunakan SPSS 22. Hasil penelitian ini menunjukkan variabel kepemilikan institusional tidak berpengaruh signifikan terhadap nilai perusahaan. Variabel dewan komisaris independen tidak berpengaruh signifikan terhadap nilai perusahaan. Sementara variabel komite audit berpengaruh signifikan terhadap nilai perusahaan. Simpulan dari penelitian ini adalah keberadaan komite audit mempunyai peran yang dapat meningkatkan nilai perusahaan melalui kualitas komite audit. Sedangkan untuk kepemilikan institusional dan jumlah dewan komisaris independen tidak mempengaruhi nilai perusahaan.
\end{abstract}

Kata Kunci: kepemilikan institusional, komisaris independen, komite audit, nilai perusahaan.

Corresponding author: fitri_amaliyah89@yahoo.com

Email addresses for author: fitri_amaliyah89@yahoo.com.elly_idc@yahoo.com

First submission received: 22 Agustus 2019

Revised submission received: 23 Oktober 2019

Accepted: 24 Oktober 2019 


\section{PENDAHULUAN}

Perusahaan merupakan organisasi yang berfungsi mengelola sumber daya untuk menghasilkan produk dengan tujuan utamanya meningkatkan kesejahteraan atau memaksimalkan kekayaan pemegang saham. Memaksimalkan kekayaan pemegang saham dapat diwujudkan dengan cara meningkatkan nilai perusahaan. Pemegang saham lebih tertarik untuk berinvestasi ke perusahaan jika kemakmuran pemegang saham menunjukan nilai yang tinggi yang akan dapat meningkatkan nilai perusahaan (Thaharah \& Asyik, 2016). Fenomena yang terjadi yaitu pada harga saham perusahaan pertambangan mengalami banyak penurunan sepanjang tahun 2017. Harga saham perusahaan pertambangan semakin melemah di tahun 2018. Penurunan saham pada sektor pertambangan tercatat sebesar $1,24 \%$. Perusahaan yang mengalami penurunan seperti perusahaan ANTM turun sebesar 2,82\% menjadi Rp 2.480,-, ADRO turun sebesar 2,28\% menjadi Rp 1.070,- per saham, PTBA turun sebesar 2,36\% menjadi Rp 2.480,- ITMG turun sebesar 2,66\%, INCO turun sebesar 0,31\%, TINS turun sebesar 2,01\%, dan MEDC turn sebesar 2,47\%. Penurunan saham tersebut terjadi karena adanya perang dagang antara Amerika Serikat dan negara Tiongkok (www.katadata.co.id).

Nilai perusahaan merupakan persepsi pemegang saham terhadap pencapaian keberhasilan perusahaan dalam mengelola sumber daya yang dimiliki yang tercermin dalam harga saham perusahaan tersebut (Saifi \& Hidayat, 2017). Meningkatkan nilai perusahaan dapat tercapai jika adanya kerjasama yang dilakukan oleh manajemen perusahaan dan komponen yang lain termasuk pemegang saham dan pemangku kepentingan dalam membuat keputusan keuangan dengan tujuan memaksimalkan modal. Namun, perusahaan biasanya dalam meningkatkan nilai perusahaan akan timbul adanya konflik kepentingan yaitu antara pemilik perusahaan dan manajemen yang disebut dengan istilah agency problem yang dapat menyebabkan timbulnya konflik keagenan (agency conflict). Pihak manajer mempunyai kewenangan untuk bertindak sesuai kepentingan pribadi dan mengorbankan kepentingan para pemegang saham. Perbedaan kepentingan antara manajer dan stakeholder inilah yang melatarbelakangi perlunya implementasi pengelolaan perusahaan yang baik. Tata kelola perusahaan yang baik menjadi salah satu solusi untuk dapat meningkatkan nilai perusahaan. kepentingan agen harus selaras dengan prinsipal untuk mengurangi adanya konflik keagenan (Jensen \& Meckling, 1976).

Tata kelola perusahaan yang baik (Good Corporate Governance) dapat memberikan sinyal adanya kepentingan yang selaras antara semua stakeholder sehingga mengurangi konflik. Selain itu, manajemen perusahaan juga dapat mencapai tujuan perusahaan yaitu meningkatkan nilai perusahaan (Widuri, Wibowo, \& Yohananes, 2017). Pada tahun 2016 CLSA Asia Pasifik Markets berkolaborasi dengan Asian Corporate Governance Association (ACGA) melakukan riset mengenai pelaksanaan corporate governance terhadap sebelas negara di Asia. Dari hasil riset tersebut Indonesia berada pada urutan terbawah dalam hal pelaksanaan corporate governance di Asia. Hal tersebut terjadi disebabkan oleh beberapa faktor baik faktor internal maupun faktor eksternal. Dalam mencapai Good Corporate Governance dibutuhkan peran dari kepemilikan institusional. Kepemilikan institusi memberikan peran penting yaitu untuk mendorong peningkatan pengawasan kepada manajemen yang lebih optimal. Selain peran dari kepemilikan institusi, juga dibutuhkan peran dari dewan komisaris independen dan komite audit. Komisaris independen berfungsi untuk menjadi penyeimbangkan dalam pengambilan keputusan yaitu mempunyai anggota dewan komisaris yang berasal dari luar perusahaan (Kusumaningtyas \& Andayani, 2015). Komite audit menjadi salah satu mekanisme tata kelola perusahaan utama yang menjadi dasar para stakeholder dalam membatasi perilaku manajer di perusahaan (Gendron \& Be, 2006).

Penelitian-penelitian sebelumnya tentang variabel-variabel yang berpengaruh terhadap nilai perusahaan masih mengalami hasil yang berbeda (inkonsisten). Amrizal (2016) dan 
Thaharah \& Asyik (2016) menjelaskan bahwa kepemilikan institusional mempunyai pengaruh signifikan terhadap nilai perusahaan. Namun, hasil tersebut tidak sama dengan penelitian yang dilakukan oleh Veronica (2013) yang menyatakan bahwa kepemilikan institusional tidak mempunyai pengaruh yang signifikan terhadap nilai perusahaan. Thaharah \& Asyik (2016) dan Saifi \& Hidayat (2017) menemukan hasil yaitu dewan komisaris independen berpengaruh terhadap nilai perusahaan. Hasil penelitian tersebut tidak sama hasilnya dengan penelitian yang dilakukan oleh Kusumaningtyas \& Andayani (2015), Amrizal (2016) dan Veronica (2013) yang memberikan hasil bahwa dewan komisaris independen tidak berpengaruh secara signifikan terhadap nilai perusahaan. Penelitian yang dilakukan Thaharah \& Asyik (2016) menunjukkan bahwa komite audit berpengaruh signifikan terhadap nilai perusahaan. Hasil ini berbeda dengan penelitian yang dilakukan oleh Amrizal (2016), Veronica (2013), dan Saifi \& Hidayat (2017) yang menyatakan bahwa komite audit tidak berpengaruh secara signifikan terhadap nilai perusahaan.

Penelitian ini bertujuan untuk memberikan bukti bahwa kepemilikan institusional, dewan komisaris independen dan komite audit berpengaruh terhadap nilai perusahaan yang merujuk kepada Agency Theory dan Signaling Theory. Keaslian pada penelitian ini ditunjukan dengan adanya perbedaan dengan penelitian sebelumnya yaitu adanya perbedaan variabel penelitian dan pemilihan populasi yaitu sektor pertambangan karena pada penelitian sebelumnya mengunakan sub sektor perkebunan, food and baverages, perbankan dan LQ 45.

\section{KERANGKA TEORITIS DAN HIPOTESIS}

\section{Teori Keagenan (Agency Theory)}

Jensen dan Meckling (1976) menyatakan hubungan keagenan di dalam teori agensi (agency theory) bahwa perusahaan adalah kumpulan kontrak antara pemilik dan manajemen yang mengelola dan mengendalikan sumber daya tersebut. Konflik kepentingan antara pemilik dan agen seringnya terjadi karena kemungkinan besar agen dalam menjalankan wewenangnya tidak sesuai dengan kepentingan prinsipal, sehingga dapat memicu adanya biaya keagenan yang tinggi. Manajer sebagai agen mempunyai tanggung jawab moral kepada para pemilik untuk mengoptimalkan keuntungan dengan cara memperoleh kompensasi yang sesuai dengan kontrak.

Konflik agensi yang sering terjadi dalam upaya memaksimalkan nilai perusahaan dapat diminimalisir dengan melalui penerapan tata kelola perusahaan yang baik (good corporate governance). Tujuan dari perbaikan tata kelola perusahaan adalah untuk mengurangi adanya konflik keagenan, sehingga daya saing perusahaan dan nilai perusahaan dapat meningkat. Selain itu, juga memberikan nilai tambah untuk semua pihak bagi yang berkepentingan secara continue dalam jangka panjang. Keberadaan good corporate governance mampu menjadi sebuah kebutuhan yang dapat menjembatani antara pihak investor dan pihak manajemen perusahaan (Saifi \& Hidayat, 2017).

\section{Teori Persinyalan (Signaling Theory)}

Menurut teori persinyalan, isyarat atau sinyal adalah sebuah tindakan yang dilakukan manajemen perusahaan dengan cara memberikan petunjuk kepada investor tentang bagaimana cara manajemen memandang prospek yang menguntungkan untuk menghindari penjualan saham serta mengusahakan setiap modal baru dengan cara yang lain (Brigham \& Houston, 2001). Teori pensinyalan menekankan pada pentingnya sebuah informasi yang diberikan oleh perusahaan yang dapat menghasilkan keputusan investasi oleh pihak dari luar perusahaan.

Teori persinyalan menekankan bahwa suatu informasi sangat penting yang dijadikan sebagai dasar oleh pihak luar dalam melakukan investasi, maka bagi perusahaan yang 
mengungkapkan informasi lebih lengkap memiliki nilai lebih menurut investor. Berdasarkan teori ini, perusahaan yang baik akan secara sengaja memberikan informasi selengkaplengkapnya sebagai sinyal positif kepada calon investor. Informasi yang relevan dapat memcerminkan kualitas perusahaan, sehingga akan dapat meningkatkan pula nilai perusahaan (Habbash, 2016).

\section{Nilai Perusahaan}

Nilai perusahaan biasanya menggambarkan kemampuan suatu perusahaan untuk memberikan kepada pemangku kepentingan perusahaan untuk mendapatkan pengembalian di bawah manajemen serta peraturan hukum yang berpusat pada nilai (Liu \& Zhang, 2016). Nilai perusahaan lebih sering dikaitkan melalui harga saham pada perusahaan yang dapat memberikan persepsi kepada investor terhadap perusahaan (Saifi \& Hidayat, 2017). Nilai perusahaan yang tinggi dapat membuat investor lebih percaya bahwa tidak hanya pada kinerja perusahaan saat ini, namun juga pada prospek perusahaan di masa yang akan datang(Rouf, 2011). Teori yang dikemukakan oleh Modigliani dan Miller menjelaskan bahwa nilai perusahaan dapat ditentukan oleh earnings power dari aset perusahaan. Nilai perusahaan (Market Value of The firm) terdiri dari nilai hutang dan nilai saham dibanding nilai asset (dalam (Ratih \& Setyarini, 2014). Nilai perusahaan menurut Brigham \& Houston (2013), manajemen menggunakan berbagai kebijakan untuk dapat memaksimalkan nilai perusahaan melalui peningkatan kemakmuran pemilik dan pemegang saham yang dapat dilihat dalam harga saham.

\section{Kepemilikan Institusional}

Kepemilikan Institusional adalah suatu proporsi kepemilikan saham institusi dalam hal ini yaitu institusi pendiri perusahaan, bukan merupakan institusi pemegang saham publik yang diukur dengan presentase jumlah saham yang dimiliki oleh investor institusi intern. Pengaruh kepemilikan institusional dijadikan sebagai agen pengawas yang ditekan melalui investasi yang cukup besar dalam pasar modal. Dengan kepemilikan institusional yang tinggi maka juga dapat menimbulkan pengawasan yang lebih besar oleh pihak investor institusional sehingga dapat menghalangi opportunistic manajer (Amrizal, 2016).

Menurut Jensen dan Meckling (1976) menjelaskan bahwa kepemilikan institusional memiliki peran yang sangat besar untuk meminimalisasi adanya konflik keagenan yang sering terjadi antara manajer dan pemegang saham. Selain itu keberadaan kepemilikan institusional juga dapat dianggap mampu unruk menjadi mekanisme pengawasan terhadap keputusan yang diambil oleh pihak manajemen. Hal tersebut dikarenakan para investor institusional terlibat dalam pengambilan keputusan yang strategis sehingga tidak mudah percaya terhadap suatu tindakan memanipulasi laba perusahaan.

\section{Dewan Komisaris Independen}

Menurut FCGI Dewan Komisaris adalah bagian inti dari corporate governance yang diberi tugas untuk menjamin pelaksanaan strategi yang diterapkan oleh perusahaan, mengawasi manajemen dalam mengelola perusahaan, serta mewajibkan terlaksananya akuntabilitas. Pada intinya, dewan komisaris merupakan suatu mekanisme untuk mengawasi dan mekanisme untuk memberikan petunjuk serta arahan bagi pengelola perusahaan. Dewan Komisaris memegang peran yang sangat penting bagi perusahaan, terutama dalam implementasi mekanisme corporate governance. Komisaris independen mempunyai fungi yaitu menjadi penyeimbang dalam mengambil keputusan yang beranggotakan dewan komisaris yang berasal dari luar perusahaan (Kusumaningtyas \& Andayani, 2015). 


\section{Komite Audit}

Komite audit merupakan sebuah komite yang dibentuk oleh dewan komisaris untuk melaksanakan fungsi pengawasan pengelolaan perusahaan. Jumlah keanggotaan komite audit diwajibkan memiliki anggota sekurang-kurangnya tiga orang, dimana yang ditugaskan menjadi ketua adalah seorang komisaris independen perusahaan dan anggota lainnya yaitu orang yang berasal dari pihak eksternal perusahaan yang bersifat independen serta dapat mempunyai latar belakang atau pengalaman di bidang keuangan dan juga akuntansi (Saifi \& Hidayat, 2017).

Keberadaan komite audit juga memberikan peranan penting dalam menjamin terciptanya corporate governance yang baik dalam perusahaan. Komite audit memiliki tugas untuk memberikan masukan profesional yang independen kepada dewan komisaris terhadap laporan yang disampaikan oleh pihak direksi kepada dewan komisaris. Selain itu, komite audit juga bertugas meninjau hal-hal yang memerlukan perhatian dari dewan komisaris serta bertanggung jawab untuk mengawasi laporan keuangan perusahaan, mengawasi audit eksternal dan mengamati sistem pengendalian internal perushaan.

\section{Model Penelitian}

Berikut adalah model penelitian untuk pengembangan hipotesis penelitian:

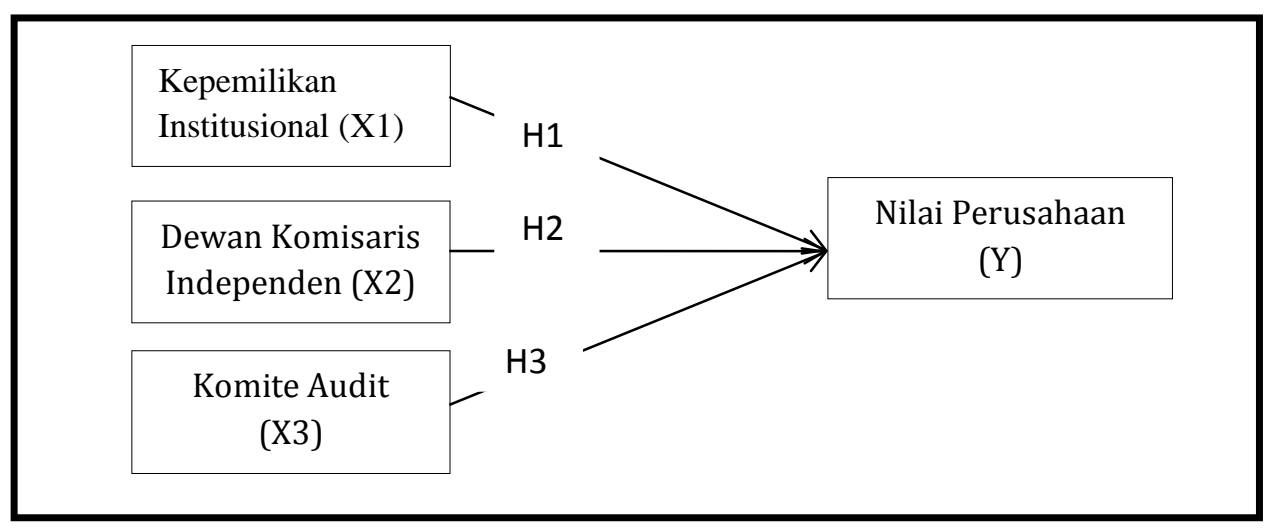

Gambar 1. Model Penelitian

\section{Hipotesis Penelitian}

\section{Pengaruh Kepemilikan Institusional Terhadap Nilai Perusahaan}

Kepemilikan Institusional di anggap mampu memberikan dampak bagi nilai perusahaan karena pada umumnya dapat bertindak sebagai pihak yang mengawasi perusahaan. Menurut Amrizal (2016) semakin besar kepemilikan institusional dalam perusahaan maka semakin besar pula dorongan untuk dapat mengoptimalkan nilai perusahaan. Kepemilikan institusional mempunyai kemampuan untuk mengendalikan dan memonitoring manajemen secara efektif supaya dapat meningkatkan kinerja manajemen.

Menurut Teori Keagenan (Jensen dan Meckling, 1976) menjelaskan bahwa semakin besar persentase saham yang dimiliki oleh investor institusional maka akan menyebabkan aktivitas pengawasan menjadi semakin efektif karena perilaku oportunis yang dilakukan oleh para manajer dapat dikendalikan. Penelitian yang dilakukan oleh Amrizal (2016) dan Thaharah \& Asyik (2016) serta Saifi \& Hidayat, (2017) menyatakan bahwa kepemilikan institusional mempunyai pengaruh yang signifikan terhadap nilai perusahaan, sedangkan menurut (Srimindarti \& Puspitasari, 2012) dan (Kusumaningtyas \& Andayani, 2015) kepemilikan institusional tidak berpengaruh signifikan terhadap nilai perusahaan. Berdasarkan penelasan teori dan hasil penelitian terdahulu maka hipotesis yang diajukan adalah:

H1 : Kepemilikan institusional berpengaruh positif terhadap nilai perusahaan. 


\section{Pengaruh Dewan Komisaris Independen Terhadap Nilai Perusahaan}

Dewan komisaris merupakan sebuah dewan yang bertugas untuk melakukan pengawasan kegiatan suatu perusahaan. Keberadaan adanya dewan komisaris independen menjadi sangat penting karena dalam praktik sering ditemukan transaksi yang mengandung unsure perbedaan kepentingan dalam perusahaan publik. Komisaris independen mempunyai tanggung jawab yaitu mendorong diimplementasikannya prinsip tata kelola perusahaan yang baik. Menurut teori keagenan (Jensen \& Meckling, 1976), dewan komisaris independen dianggap sebagai mekanisme pengendalian intern tertinggi yang bertanggung jawab untuk memonitor kebijakan manajemen puncak. Dalam teori keagenan menyatakan jumlah anggota dewan komisaris independen yang besar, akan mempermudah dalam mengendalikan manajemen puncak dan fungsi monitoring akan semakin efektif yang pada akhirnya menaikkan nilai perusahaan. Penelitian yang dilakukan (Thaharah \& Asyik, 2016) dan (Saifi \& Hidayat, 2017) menyimpulkan bahwa dewan komisaris independen berpengaruh positif terhadap nilai perusahaan. Sedangkan menurut (Amrizal, 2016) dan (Veronica, 2013) serta (Aryanto \& Setyorini, 2019) dewan komisaris independen tidak memberikan pengaruh signifikan terhadap nilai perusahaan. Berdasarkan teori dan hasil penelitian terdahulu maka hipotesis yang diajukan adalah:

H2 : Dewan komisaris independen berpengaruh positif terhadap nilai perusahaan.

\section{Pengaruh Komite Audit Terhadap Nilai Perusahaan}

Komite audit merupakan salah satu mekanisme utama yang ada di tata kelola perusahaan yang dijadikan sebagai dasar harapan para pemangku kepentingan untuk membatasi perilaku manajer perusahaan (Gendron \& Be, 2006). Kkomite audit mempunyai tugas utama yaitu mengawasi proses pelaporan keuangan untuk memastikan manajer melaporkan kinerja perusahaan mereka secara etis. Menurut teori keagenan (Jensen \& Meckling, 1976), komite audit akan mengurangi konflik keagenan karena komite audit bertugas melindungi kepentingan pemegang saham dari adanya tindakan manajemen laba yang biasanya dilakukan oleh pihak manajemen. Apabila efektifitas komite audit dapat tercapai, maka transparansi pertanggungjawaban manajemen perusahaan akan dapat dipercaya. Sehingga kepercayaan para investor pun akan meningkat. Adanya pengawasan dari komite audit akan memastikan pencapaian kinerjaperusahaan dan mampu meningkatkan nilai perusahaan. Hasil penelitian (Thaharah \& Asyik, 2016) menyimpulkan bahwa komite audit berpengaruh positif terhadap nilai perusahaan. Sedangkan penelitian yang dilakukan oleh (Amrizal, 2016), (Veronica, 2013) dan (Saifi \& Hidayat, 2017) tidak memberikan pengaruh yang signifikan terhadap nilai perusahaan. Berdasarkan teori dan hasil penelitian terdahulu maka hipotesis yang diajukan adalah:

H3 : Komite audit berpengaruh positif terhadap nilai perusahaan.

\section{METODE PENELITIAN}

\section{DesainPenelitian}

Penelitian ini merupakan sebuah penelitian kuantitatif dengan melakukan studi empiris pada perusahaan yang terdaftar di Bursa Efek Indonesia (BEI) khususnya perusahaan sektor pertambangan selama tahun 2017-2018. Penelitian kuantitatif dapat diartikan sebagai metode penelitian yang berlandasan positivisme yang digunakan untuk menelitipopulasi atau sampel tertentuyang bertujuan untuk menguji hipotesis yang telah ditetapkan(Sugiyono, 2014). 


\section{Populasi dan Sampel Penelitian}

Populasi dalam penelitian ini adalah perusahaan sektor pertambangan yang terdaftar di Bursa Efek Indonesia tahun 2017-2018. Pengambilan sampel dilakukan dengan menggunakan purposive sampling dengan tujuan mendapatkan sampel yang sesuai dengan kriteria yang ditentukan, yaitu:

1) Perusahaan sektor pertambangan yang terdaftar di Bursa Efek Indonesia periode tahun2017-2018.

2) Perusahaan sektor pertambangan menyediakan laporan tahunan lengkap yang sudah diaudit periode tahun 2017-2018.

3) Perusahaan memiliki informasi data lengkap terkait dengan variabel-variabel yang diteliti. Tabel 1.

Jumlah sampel perusahaan

\begin{tabular}{lc}
\hline \multicolumn{1}{c}{ Keterangan } & Jumlah \\
\hline Perusahaan pertambangan yang terdaftar 2017-2018 & 98 \\
\hline Perusahaan yang tidak menyediakan laporan tahunan & $(28)$ \\
\hline Perusahaan yang tidak menginformasikan variabel terkait & $(10)$ \\
\hline Sampel penelitian & 60 \\
\hline
\end{tabular}

Sumber: Laporan Tahunan Perusahaan Pertambangan 2017-2018

\section{Operasional Variabel}

Variabel pada penelitian ini adalah nilai perusahaan sebagai variabel dependen. Sedangkan kepemilikan institusional, dewan komisaris independen dan komite audit sebagai variabel independen. Definisi operasional variabel dapat dilihat pada tabel dibawah ini:

Tabel 2. Definisi Operasional Variabel

\begin{tabular}{|c|c|c|c|}
\hline No & $\begin{array}{l}\text { Variabel } \\
\text { Penelitian }\end{array}$ & Definisi Operasional & Indikator \\
\hline 1 & $\begin{array}{l}\text { Nilai } \\
\text { Perusahaan } \\
\text { (Y) }\end{array}$ & $\begin{array}{l}\text { Nilai perusahaan merupakan } \\
\text { gambaran keadaan sebuah } \\
\text { perusahaan, dimana terdapat } \\
\text { penilaian khusus oleh calon } \\
\text { investor terhadap baik } \\
\text { buruknya kinerja keuangan } \\
\text { perusahaan (Amrizal, 2016) }\end{array}$ & $\begin{array}{l}\text { Proksi yang digunakan untuk } \\
\text { mengukur nilai perusahaan adalah } \\
\text { Price Book Value (PBV).Dapat } \\
\text { dihitung menggunakan rumus: } \\
\text { PBV }=\frac{\text { Harga PasarPer Lembar Saham }}{\text { Nilai Buku Per Lembar Saham }}\end{array}$ \\
\hline 2 & $\begin{array}{l}\text { Kepemilikan } \\
\text { intitusional } \\
\text { (X1) }\end{array}$ & 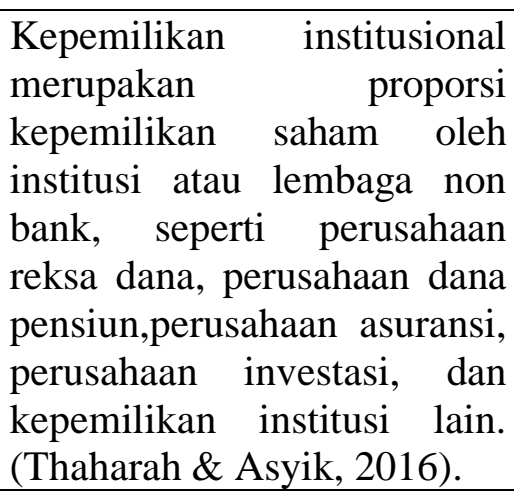 & $\begin{array}{l}\text { Kepemilikan saham institusional } \\
\text { diukur dengan cara membagi jumlah } \\
\text { saham investor institusional dibagi } \\
\text { jumlah saham beredar. } \\
\text { KI }=\frac{\sum \text { Saham investor institusional }}{\sum \text { Saham beredar }}\end{array}$ \\
\hline 3 & $\begin{array}{l}\text { Dewan } \\
\text { Komisaris }\end{array}$ & $\begin{array}{l}\text { Komisaris Independen adalah } \\
\text { sebuah badan dalam } \\
\text { perusahaan yang anggotanya }\end{array}$ & $\begin{array}{l}\text { Variabel ini diukur dengan membagi } \\
\text { jumlah dewan komisaris independen }\end{array}$ \\
\hline
\end{tabular}


Fitri Amaliyah dan Eliada Herwiyanti

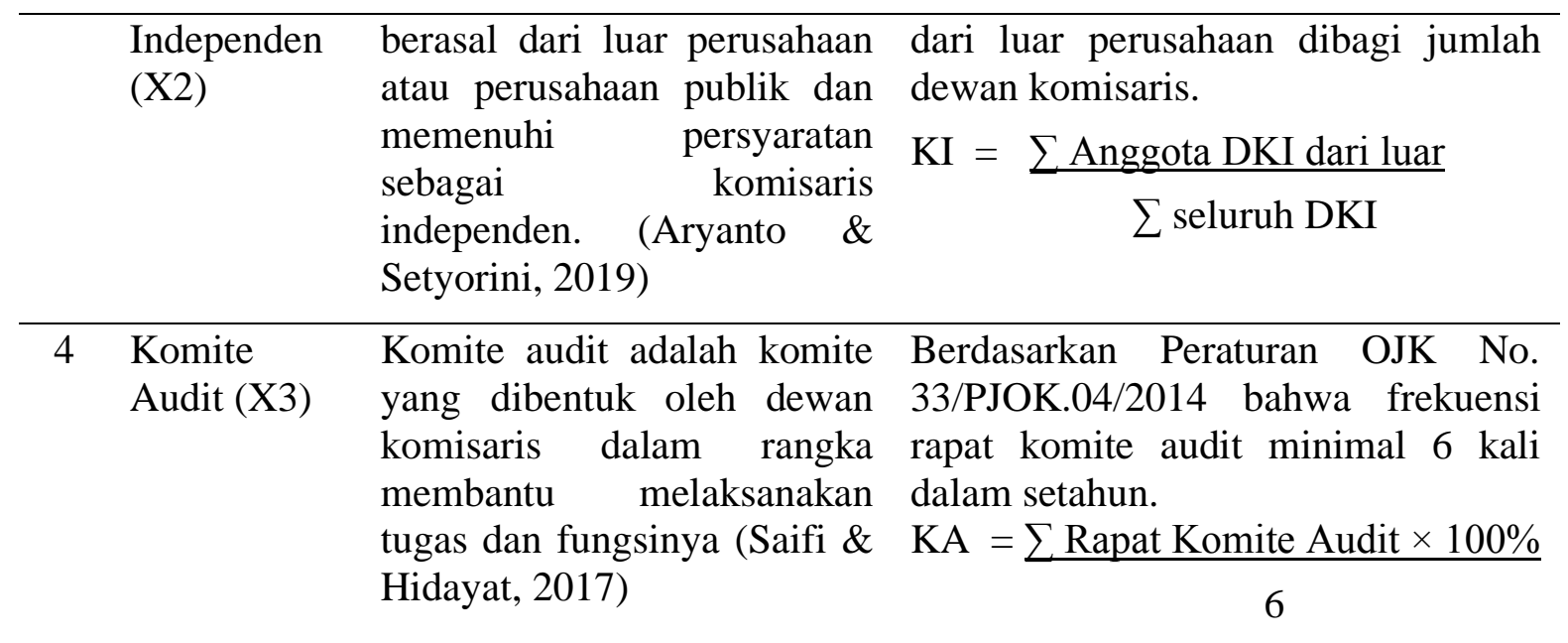

\section{Teknik Pengumpulan Data}

Teknik pengumpulan data pada penelitian ini dilakukan dengan metode dokumentasi dan studi pustaka. Metode dokumentasi dilakukan dengan mengumpulkan sumber-sumber data sekunder seperti laporan tahunan(financial report) dan laporan tahunan(annual report) padaperusahaan yang menjadi sampel penelitian melalui situs BEI yaitu www.idx.co.id dan website resmi perusahaan. Studi pustaka pada penelitian ini dilakukan dengan mengumpulkan dan mengolah data dari literatur seperti buku, artikel, jurnal maupun media cetak lain yang berkaitan dengan tema penelitian.

\section{Metode Analisis}

Metode analisis data yang digunakan dalam penelitian ini adalah menggunakan analisis regresi berganda (multi-regression). Analisis ini dipergunakan untuk mengetahui dan memperoleh gambaran mengenai pengaruh kepemilikan institusional, dewan komisaris independen dan komite audit terhadap nilai perusahaan pada perusahaan sektor pertambangan di Bursa Efek Indonesia tahun 2017-2018. Dalam menganaisis data dengan regresi linier berganda dengan beberapa uji sebagai berikut : (1)Analisis Statistik Deskriptif, (2) Uji Asumsi Klasik (uji normalitas, uji multikolinearitas, uji autokolerasi, dan uji heterokedastisitas), (3) Uji hipotesis dan uji koefisien determinasi. berikut:

Model persamaan yang digunakan untuk menguji hipotesis dalam penelitian ini sebagai

$$
\begin{aligned}
& \mathbf{Y = \alpha}+\boldsymbol{\beta 1} \text { KI }+\boldsymbol{\beta 2} \text { DKI }+\boldsymbol{\beta 3} \mathbf{K A}+\mathbf{e} \\
& \text { Keterangan: } \\
& \mathrm{Y} \quad=\text { Nilai perusahaan } \\
& \alpha \quad=\text { Konstanta } \\
& \beta \quad=\text { Koefisien regresi variabel } \\
& \mathrm{KI} \quad=\text { Kepemilikan Institusional } \\
& \text { DKI } \quad=\text { Dewan Komisaris Independen } \\
& \mathrm{KA} \quad=\text { Komite Audit }
\end{aligned}
$$

\section{HASIL DAN PEMBAHASAN}

\section{Analisis StatistikDeskriptif}

Hasil analisis statistik deskriptif dalam penelitian ini adalah sebagai berikut: 
Tabel 3.

Hasil Statistik Deskriptif

\begin{tabular}{lrrrrr}
\hline & $\mathrm{N}$ & Minimum & Maximum & \multicolumn{1}{c}{ Mean } & $\begin{array}{c}\text { Std. } \\
\text { Deviation }\end{array}$ \\
\hline KI (X1) & 60 & 0,01 & 1,00 & 0,7212 & 0,24494 \\
\hline DKI (X2) & 60 & 0,29 & 0,67 & 0,3955 & 0,07556 \\
\hline KA (X3) & 60 & 0,50 & 9,83 & 1,5478 & 1,55675 \\
\hline NP (Y) & 60 & 43,68 & 17,70 & 15,0222 & 2,65950 \\
\hline Valid N (listwise) & 60 & & & & \\
\hline
\end{tabular}

Dari uji statistik deskriptif diatas dapat diketahui bahwa nilai rata-rata dari nilai perusahaan (NP) adalah sebesar 15,0222 dan standar deviasi sebesar 0,24494. Standar deviasi dengan nilai lebih kecil dibandingkan nilai rata-rata menunjukkan bahwa rendahnya simpangan data variabel nilai perusahaan selama periode pengamatan. Kepemilikann institusional memiliki nilai mean sebesar 0,7212 dan standar deviasinya sebesar 0,24494 . Nilai rata-rata dewan komisaris independen (DKI) sebesar 0,3955dan standar deviasinya sebesar 0,07556. Standar deviasi yang lebih kecil dari nilai rata-rata menunjukkan bahwa rendahnya simpangan data variabel (DKI) selama periode pengamatan. Nilai rata-rata komite audit (KA) sebesar 1,5478 dan standar deviasinya sebesar 1,55675. Standar deviasi yang nilainya lebih tinggi dibandingkan nilai rata-rata menunjukkan bahwa tingginya simpangan data variabel komite audit (KA) selama periode pengamatan. Hal ini berarti data bersifat heterogen dan mencerminkan penyimpangan data yang sangat tinggi.

\section{Uji Asumsi Klasik}

Uji normalitas adalah sebuah uji yang dilakukan untuk menguji apakah nilai residual yang telah distandarisasi memiliki distribusi normal (Suliyanto, 2011). Berdasarkan hasil uji Kolmogorov-Smirnovmenunjukkan bahwa nilai sig. sebesar 0,200>0,05. Artinya nilai residual terstandarisasi dinyatakan menyebar secara normal.

Tabel 4.

Hasil Uji Kolmogorov-Smirnov

\begin{tabular}{lc}
\hline & Standardized Residual \\
\hline Test Statistic & 0,065 \\
\hline Asymp. Sig. (2-tailed) & 0,200 \\
\hline
\end{tabular}

Uji multikolinearitas adalah sebuah uji yang dilakukan dengan bertujuan untuk menguji apakah model regresi ditemukan adanya korelasi antar variabel bebas (independen) (Suliyanto, 2011). Dari uji multikolonieritas menunjukkan bahwa nilai tolerance dari setiap variabel independen lebih dari 0,10 dan nilai VIF dari setiap variabel independen tidak lebih dari 10. Dari hasil tersebut dapat disimpulkan bahwa pada model regresi tidak ada multikolonieritas antar variabel independen. Sehingga model regresi penelitian dapat diterima dan layak digunakan.

Tabel 5. Hasil Uji Multikolinearitas

\begin{tabular}{|c|c|c|}
\hline \multirow{2}{*}{ Model } & \multicolumn{2}{|c|}{ Collinearity Statistics } \\
\hline & Tolerance & VIF \\
\hline KI & 0,973 & 1,028 \\
\hline DKI & 0,908 & 1,102 \\
\hline KA & 0,892 & 1,12 \\
\hline
\end{tabular}


Uji heterokedastisitas adalah sebuah uji yang dilakukan dengan tujuan untuk mengetahui ada atau tidaknya penyimpangan yaitu adanya ketidaksamaan nilai varian dari residual untuk semua pengalaman pada model regresi. Dalam penelitian ini uji heterokedastisitas dilakukan denganmenggunakan grafik scatterplot untuk melihat adakah pola tertentu antara variabel terikat (ZPRED) dengan variabel bebas (SRESID). Berikut merupakan grafik scatterplot dalam penelitian ini:

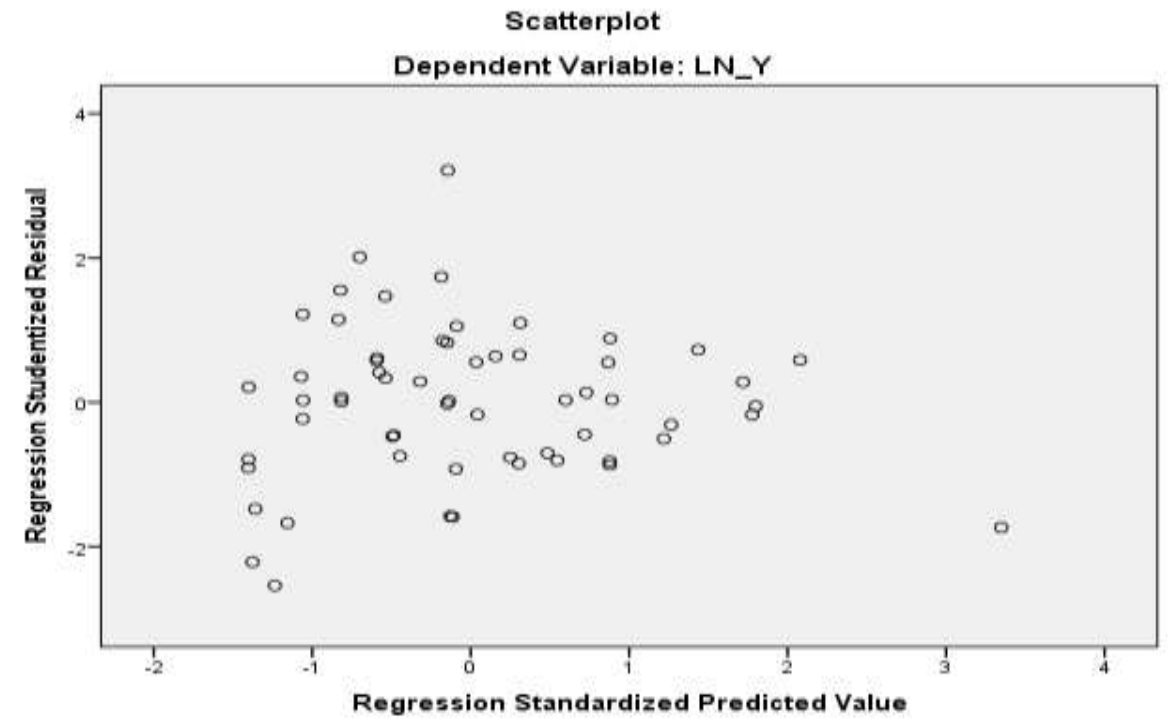

Gambar 1Uji Heteroskedastisitas

Berdasarkan Gambar di atas dapat dilihat bahwa penyebaran pola yang merata diatas dan dibawah titik 0 dan juga tidak membentuk pola tertentu. Berdasarkan gambar di atas maka dapat disimpulkan bahwa dalam model penelitian ini tidak terjadi permasalahan heteroskedastisitas.

\section{Uji Autokolerasi}

Uji autokolerasi menggunakan metode Durbin Watson. Dari uji autokolerasi menunjukkan nilai Durbin Watson sebesar 1,941. Nilai tersebut dibandingkan dengan nilai tabel Durbin Watson dengan menggunakan tingkat signifikansi 0,05 $(\alpha=5 \%)$, jumlah variabel bebas $3(\mathrm{k}=3)$, dan jumlah data sampel $60(\mathrm{n}=60)$. Diperoleh nilai $\mathrm{dL}=1,469$ dan $\mathrm{dU}=1,686$, sehingga nilai 4-dL=2,531 dan 4-dU=2,314. Nilai DW sebesar 1,941 yang berarti bahwa dalam model regresi tidak terdapat autokolerasi.

\section{Analisis Regresi Linier Berganda dan Uji t}

Hasil analisis regresi linier berganda pada penelitian ini adalah sebagai berikut:

Tabel 6.

Hasil Analisis Regresi Linier Berganda

\begin{tabular}{lrrrr}
\hline \multirow{2}{*}{ Model } & \multicolumn{2}{c}{ Unstandardized Coefficients } & t & Sig. \\
\cline { 2 - 3 } & $\mathrm{B}$ & \multicolumn{1}{c}{ Std Error } & & \\
\hline (Constant) & 27,309 & 1,141 & 27,309 & 0,000 \\
\hline KI & $-0,028$ & 0,265 & $-0,227$ & 0,821 \\
\hline DKI & 0,237 & 1,209 & 1,884 & 0,065 \\
\hline KA & 0,455 & 0,333 & 3,589 & 0,001 \\
\hline
\end{tabular}


Dari tabel 6 dapat diketahui persamaan regresi adalah sebagai berikut:

$\mathrm{Y}=27,309-0,028 \mathrm{KI}+0,237 \mathrm{DKI}+0,455 \mathrm{KA}+\mathrm{e}$

Konstanta sebesar 27,309 menyatakan bahwa jika variabel independen dianggap konstan, maka rata-rata nilai perusahaan sebesar 27,309. Koefisien regresi KI sebesar -0,028 menyatakanbahwa setiap peningkatandewan komisaris independen sebesar 1akan menurunkan nilai perusahaan sebesar -0,028. Koefisien regresi DKI sebesar 0,237 menyatakan bahwa setiap peningkatan dewan komisaris independen sebesar 1akan meningkatkan nilai perusahaan sebesar 0,237. Koefisien regresi KA sebesar 0,455 menyatakan bahwa setiap peningkatan komite audit sebesar 1 akan meningkatkan nilai perusahaan sebesar 0,455. Dari hasil uji t mengindikasikan bahwa variabel dewan komisaris independen (KI) memiliki nilai t sebesar 0,227dengan tingkat signifikansi sebesar 0,821lebih besar dari taraf signifikansi (5\%). Dari hasil tersebut dapat disimpulkan bahwa variabel dewan komisaris independen tidak berpengaruh signifikan terhadap nilai perusahaan. Dari uji t diketahui bahwa variabel komite audit (DKI) memiliki nilai t sebesar 1,884 dengan tingkat signifikansi sebesar 0,065 lebih besar dari taraf signifikansi 0,05 (5\%). Dari hasil tersebut dapat disimpulkan bahwa variabel dewan komisaris independen tidak berpengaruh signifikan terhadap nilai perusahaan. Dari uji $\mathrm{t}$ diketahui bahwa variabel komite audit (KA) memiliki nilai t sebesar 3,589 dengan tingkat signifikansi sebesar 0,001 yang nilainya lebih kecil dari nilai signifikansi (5\%). Dari hasil tersebut dapat disimpulkan bahwa variabel komite audit berpengaruh signifikan terhadap nilai perusahaan.

Tabel 7.

Hasil Analisis Uji F

\begin{tabular}{lccccc}
\hline \multicolumn{1}{c}{ Model } & Sum of Squares & df & Mean Square & F & Sig. \\
\hline Regression & 34.744 & 3 & 11.581 & 4.580 & $.006^{\mathrm{b}}$ \\
\hline Residual & 141.615 & 56 & 2.529 & & \\
\hline Total & 176.358 & 59 & & & \\
\hline
\end{tabular}

Dari tabel anova di atas didapat tingkat signifikan uji $\mathrm{F}=0,006<0.05$ (level of signifikan), yang menunjukkan pengaruh variabel bebas yang terdiri dari kepemilikan institusional, dewan komisaris independen, dan komite audit secara bersama-sama berpengaruh signifikan terhadap nilai perusahaan. Hasil ini mengindikasi bahwa naik turunnya nilai perusahaan pada perusahaan pertambangan yang terdaftar di Bursa Efek Indonesia tergantung oleh naik turunnya kepemilikan institusional, dewan komisaris independen, dan komite audit, yang dimiliki oleh perusahaan-perusahaan tersebut. Selain itu, dapat disimpulkan bahwa model layak untuk di uji.

Tabel 8.

Ringkasan Pengujian Hipotesis

\begin{tabular}{clccc}
\hline No & \multicolumn{1}{c}{ Hipotesis } & B & Sig. & Hasil \\
\hline 1 & $\begin{array}{l}\text { Kepemilikan institusional berpengaruh } \\
\text { positif terhadap nilai perusahaan }\end{array}$ & $-0,028$ & 0,821 & Ditolak \\
\hline 2 & $\begin{array}{l}\text { Dewan komisaris independen berpengaruh } \\
\text { positif terhadap nilai perusahaan }\end{array}$ & 0,237 & 0,065 & Ditolak \\
\hline 3 & $\begin{array}{l}\text { Komite audit berpengaruh positif terhadap } \\
\text { nilai perusahaan }\end{array}$ & 0,455 & 0,001 & Diterima \\
\hline
\end{tabular}




\section{Pengaruh Kepemilikan Institusional Terhadap Nilai Perusahaan}

Hasil pengujian hipotesis menunjukkan variabel kepemilikan institusional berpengaruh negatif dan tidak signifkan terhadap nilai perusahaan sehingga dapat disimpulkan H1 ditolak. Hal ini menunjukkan bahwa jika jumlah kepemilikan institusional semakin besar maka akan menurunkan nilai perusahaan. Hasil ini mencerminkan kurang efektifnya kepemilikan institusional dalam memonitor manajemen perusahaan, sehingga pengendalian perusahaan menjadi rendah dan perilaku opportunistic manajemen meningkat. The strategic alignment hypothesis menyatakan bahwa investor institusional yang memilki kepemilikan saham mayoritas akan lebih cenderung berpihak dan bekerjasama dengan pihak manajemen untuk mendahulukan kepentingan pribadinya dari pada kepentingan pemegang saham minoritas. Hal ini memberikan sinyal negatif untuk pihak luar karena strategi aliansi investor institusional dengan pihak manajemen cenderung mengambil kebijakan perusahaan secara tidak optimal. Tindakan ini dapat merugikan operasional perusahaan. Hal tersebut memberikan dampak yaitu investor tidak akan tertarik untuk menanamkan modalnya, volume perdagangan saham dan harga saham semakin menurun, serta nilai perusahaan juga akan ikut menurun.

\section{Pengaruh Dewan Komisaris Independen Terhadap Nilai Perusahaan}

Hasil pengujian hipotesis menunjukan variabel dewan komisaris independen tidak berpengaruh positif signifikan terhadap nilai perusahaan sehingga dapat disimpulkan $\mathrm{H} 2$ ditolak. Hasil ini mendukung penelitian (Kusumaningtyas \& Andayani, 2015), (Amrizal, 2016), dan (Veronica, 2013). Hasil ini menunjukkan bahwa peran dewan komisaris independen kurang efektif pada perusahaan sektor pertambangan sehingga dapat disimpulkan bahwa dewan komisaris independen tidak mampu dalam meningkatkan nilai perusahaan. Jumlah dewan komisaris independen tidak dapat dijadikan jaminan untuk meningkatkan nilai perusahaan. Hal ini kemungkinan dikarenakan keberadaan komisaris independen hanya sebagai formalitas untuk memenuhi regulasi dari Otoritas Jasa Keuangan sehingga komisaris independen tidak melaksanakan fungsi monitoring dengan baik. Data penelitian menunjukan rata-rata kepemilikan institusional yang tidak terlalu besar yaitu 39,55\% sehingga menunjukan bahwa kemampuan kepemilikan institusional dalam proses monitoring serta dalam melakukan dorongan terhadap kinerja manajemen belum efektif. Peraturan Otoritas Jasa Keuangan Nomor: 33/POJK.04/2014 yang menetapkan bahwa setiap emiten wajib memiliki komisaris independen sekurang-kurangnya 30\% dari jumlah seluruh dewan komisaris independen. Proporsi dewan komisaris independen yang dimiliki oleh perusahaan pertambangan tidak terlalu besar sehingga ada kemungkinan manajemen untuk melakukan tindakan oportunistik yang dapat menimbulkan konflik keagenan.

\section{Pengaruh Komite Audit Terhadap Nilai Perusahaan}

Hasil pengujian hipotesis menunjukan bahwa variabel komite audit berpengaruh positif signifikan terhadap nilai perusahaan sehingga dapat disimpulkan $\mathrm{H} 3$ diterima. Hasil ini sejalan dengan penelitian (Thaharah \& Asyik, 2016). Hasil ini menunjukkan bahwa komite audit mempunyai peran yang dapat meningkatkan pengawasan terhadap pelaporan keuangan yang dibuat oleh manajer. Selain itu, komite audit memiliki peran dalam menghambat perilaku manajemen dalam menekan manajemen laba. Melalui rapat komite audit dapat dipastikan pertanggungjawaban jalannya perusahaan sudah sesuai dengan ketentuan hukum dan peraturan yang berlaku Indonesia. Citra perusahaan dapat tercermin dari kualitas komite audit yang baik sehingga investor akan tertarik untuk berinvestasi yang dapat meningkatkan nilai perusahaan. 


\section{PENUTUP}

Faktor-faktor yang mempengaruhi tata kelola perusahaan (Good Corporate Governance) pada penelitian ini menunjukan bahwa kepemilikan institusional dan dewan komisaris independen tidak berpengaruh positif signifikan terhadap nilai perusahaan. Hal tersebut dapat diartikan bahwa kepemilikan institusional dan dewan komisaris independen tidak mampu dalam meningkatkan nilai perusahaan pada perusahaan sektor pertambangan. Sedangkan komite audit berpengaruh positif dan signifikan terhadap nilai perusahaan yang artinya bahwa komite audit mampu meningkatkan nilai perusahaan pada perusahaan sektor pertambangan..

Keterbatasan pada penelitian ini yaitu sampel pada perusahaan sektor pertambangan jumlahnya relatif sedikit dan untuk periode penelitian ini menggunakan rentan waktu yang cukup pendek yaitu hanya dua tahun sehingga jumlah perusahaan yang diteliti berjumlah sedikit dan terbatas sehingga hasil penelitian kurang akurat. Selain itu pada penelitian ini untuk hasil uji determinasi jumlah R2 (Adjusted) adalah $20 \%$ yang artinya masih terdapat variabel lain yang berpengaruh pada nilai perusahaan. Keterbatasan terakhir pada penelitian ini yaitu terdapat unsur subjektifitas peneliti dalam pemberian bobot dan nilai pada penilaian perusahaan yaitu menggunakan ukuran PBV.

Dari keterbatasan tersebut, maka untuk peneliti selanjutnya disarankan untuk menggunakan populasi di sektor yang lain seperti sektor perusahaan manufaktur serta memperpanjang periode pengamatan. Dengan jumlah sampel yang lebih besar diharapkan akan dapat mengeneralisasi semua jenis industri. Dan periode yang lebih lama akan memberikan hasil yang lebih akurat atau hasil yang mendekati sebenarnya. Penelitian selanjutnya juga diharapkan menambah variabel lain diluar penelitian ini, misal variabel ukuran perusahaan, rasio keuangan, corporate responsibility, manajemen laba dan beberapa variabel pengukur lainnya sehingga dapat mempengaruhi nilai perusahaan. Terdapat unsur subjektivitas dalam menentukan nilai perusahaan PBV (Price Book Value). Hal tersebut dikarenakan tidak adanya ketentuan baku yang dapat dijadikan acuan sehingga penentuan nilai perusahaan untuk indikator dalam kategori yang sama dapat berbeda untuk setiap peneliti.

Hasil penelitian ini memiliki implikasi bahwa perusahaan dalam kepemilikan institusional perlu dalam memonitor manajemen perusahaan, sehingga pengendalian perusahaan menjadi efektif dan perilaku opportunistic manajemen data menurun. Selain itu, perusahaan perlu meningkatkan fungsi monitoring dewan komisaris independen sehingga mampu meningkatkan nilai perusahaan. Komite audit sebagai pihak yang mengawasi mampu memastikan kehandalan informasi yang disajikan manajemen.

\section{DAFTAR PUSTAKA}

Amrizal, S. H. N. R. (2016). Pengaruh Kepemilikan Institusional, Dewan Komisaris Independen, Kualitas Audit, Komite Audit terhadap Nilai Perusahaan. Jurnal Akuntansi STIE Ahmad Dahlan Jakarta, 4(1), 76-89.

Aryanto, A., \& Setyorini, C. T. (2019). Pengaruh Tata Kelola Perusahaan Dan Tanggung Jawab Sosial Terhadap Nilai Perusahaan Sektor Pertambangan. Jurnal Informasi, Perpajakan, Akuntansi, Dan Keuangan Publik, 14(2), 181. https://doi.org/10.25105/jipak.v14i2.5020

Brigham, E., \& Houston, J. F. (2001). Manajemen Keuangan II. Jakarta: Salemba Empat.

Gendron, Y., \& Be, J. (2006). On the constitution of audit committee effectiveness. Accounting, Organizations and Society, 31, 211-239. https://doi.org/10.1016/j.aos.2005.03.002

Habbash, M. (2016). Corporate Governance and Corporate Social Responsibility Disclosure: 
PENGARUH KEPEMILIKAN INSTITUSIONAL, DEWAN KOMISARIS INDEPENDEN, DAN KOMITE AUDIT TERHADAP NILAI PERUSAHAAN SEKTOR PERTAMBANGAN

Fitri Amaliyah dan Eliada Herwiyanti

Evidince from Saudi Arabia. Proceedings of 10th International Scientific Conference on Economic and Social Development, (September), 267-282. https://doi.org/10.1108/SRJ07-2015-0088

Jensen, M. C., \& Meckling, W. H. (1976). Theory of the Firm : Managerial Behavior, Agency Costs and Ownership Structure. Journal of Financial and Economics, 3, 305-360.

Kusumaningtyas, T. K., \& Andayani. (2015). Pengaruh Good Corporate Governance terhadap Nilai Perusahaan yang Terdaftarpada Iindeks Sri-KKusumaningtyas, T. K., \& Andayani. (2015). Pengaruh Good Corporate Governance terhadap Nilai Perusahaan yang Terdaftarpada Iindeks Sri-Kehati. Jurnal Ilmu \& Riset. Jurnal Ilmu \& Riset Akuntansi, 4(7).

Liu, X., \& Zhang, C. (2016). Corporate governance, social responsibility information disclosure, and enterprise value in China. Journal of Cleaner Production, 142, 1075-1084. https://doi.org/10.1016/j.jclepro.2016.09.102

Ratih, S., \& Setyarini, Y. (2014). Pengaruh Good Corporate Governance (Gcg)Dan Corporate Social Responsibility(Csr)Terhadap Nilai Perusahaan Dengan Kinerja Keuangan SebagaiVariableIntervening Pada Perusahaan PertambanganYang Go Public DiBei. AKRUAL: Jurnal Akuntansi, 5(2), 115. https://doi.org/10.26740/jaj.v5n2.p115-132

Rouf, A. (2011). The Relationship Between Corporate Governance and Value of the Firm in Developing Countries: Evidence from Bangladesh. The Journal of Applied Economics and Finance, 5(3).

Saifi, M. C. S. T. M., \& Hidayat, R. R. (2017). Pengaruh Good Corporate Governance terhadap Nilai Perusahaan (Studi pada Perusahaan Sub Sektor Food and Beverages yang Terdaftar di BEI Tahun 2012-2015) Mei. E-Proceeding of Management, 4(3), 2261-2266.

Srimindarti, C., \& Puspitasari, E. (2012). PERAN KEPEMILIKAN INSTITUSIONAL , KOMISARIS INDEPENDEN , KOMITE AUDIT DAN AUDITOR EKSTERNAL. 1-15.

Sugiyono. (2014). Metode Penelitian Bisnis (Pendekatan Kuantitatif \& Kualitatif). Bandung: CV. Alfabeta.

Suliyanto. (2011). Ekonometrika Terapan - Teori dan Aplikasi dengan SPSS. Yogyakarta: Penerbit ANDI.

Thaharah \& Asyik. (2016). Pengaruh Mekanisme Corporate Governance Dan Kinerja Keuangan Terhadap Nilai Perusahaan LQ 45. Jurnal Ilmu Dan Riset Akuntansi, 5(2), 118. https://doi.org/ISSN : 2460-0585

Veronica, wardoyo \& theodora martina. (2013). pengaruh good corporate governance, CSR dan Kinerja keuangan terhadap nilai perusahaan. Jurnal Dinamika Manajemen, 4(2), 132149. Retrieved from http://journal.unnes.ac.id/nju/index.php/jdm

Widuri, K., Wibowo, B. J., \& Yohananes. (2017). The Mediating Effect ofCorporate Social Responsibility and Corporate Governanceon the Company' s Firm Value. Research Journal of Social Sciences, 10(3), 1-7. 